\title{
Institutional Basics of Tariffs in Housing and Communal Services: Cross-Country Analysis
}

\author{
Tamara N. Nerovnya ${ }^{1}$ \\ Natalya T. Oboimova ${ }^{2}$ \\ Valentina I. Rodionova ${ }^{2}$ \\ Galina P. Dovlatyan ${ }^{3}$ \\ Vladimir A. Shapovalov 2
}

${ }^{1}$ North-Caucasian Federal University, ${ }^{2}$ Don State technical University, ${ }^{3}$ South-Russian state Polytechnic University

Email:ntn200853@mail.ru

\section{Doi:10.5901/mjss.2015.v6n3p26}

\section{Abstract}

The aim of the article is a review and summarizing methods of tariffs in housing and communal services in foreign countries, and also reasoning of opportunity to use of state marketing in the regulation of tariffs and the main directions of its usage, both in Russia and abroad. The result of this article is the formulation of conclusions and predictions for further development of tariff setting, as well as the social consequences of this policy in the sphere of housing and communal services. The institutional character of the social practices of HCS, according to the authors, is associated with the provision of living conditions for the population in the sphere of material practices and with the finding of ways to optimize the economy of the industrial and postindustrial societies. In the service social practices HCS special factor is the change of goal setting, re-orientation of social action for the client from the process that is not always connected with rational components of the social actions of individuals, and also with the operation of irrational components. Besides, there is a kind of "soft" technologization in the service social practices of HCS. Pricing policy in the sphere of housing and communal services detects a contradiction, on the one hand, between a wide range of services and agents that shows the democratization processes in the maintenance and strengthening of processes of self-administration, and on the other side of rising prices and low quality of services provided.

Keywords: State marketing, tariffs, housing and communal services, social practice tariff.

\section{Introduction}

The research topic is in line with international trends of increasing of the role and relative weight of categories sector of human activity and social life. Services housing are an integral part of industrial relations, including relations of production, transfer, exchange, distribution and consumption of specific (in the form of services) vitally important goods which are related to the field of personal and collective consumption.

Foreign experience in the aspect of opportunity of its usage in the conditions of Russian specificity is not sufficiently studied and necessitates special studies. That is why it is necessary to conduct polyaspectic cross-country analysis of the institutional basics of tariffs. This will allow us to develop the concept of the forming of institutional system of housing and communal economy in the countries which realize the transition to civilized forms of management, and also to determine the principles of development of market relations in the process of interaction of subjects of the market with regard to the adaptation of foreign experience and the imperative of institutional improvement of the Russian practice.

Let us examine the impact of institutional changes in housing and communal services (hereinafter referred to as HCS) on the process of its delivery and distribution of the financial burden on the population. Implementation of reforms in HCS and the development of a new system of social subsidies for HCS services in RF and further socio-economic policy and the stability of society are not finished.

In the economic and social context housing and communal utilities (hereinafter - HCA) are an important factor in the reproduction of the main productive force of society - labour force, the creation of gross national product and national income, economic growth, increasing economic efficiency; in social context housing and communal services is resultative 
factor in the stabilization of the level of living of the population in the period of consolidation of market relations, its subsequent growth, improving the quality of life, the full realization of the principle of social justice.

Institutional design and development of effective strategic organizational and economic mechanisms of development of the sphere of housing and communal services in today's economy plays an important role in society life.

Institutionalization of elements of socio-economic reality strengthens the social practices of everyday life in any country. Institutionalization of HCS is adequate to ongoing social processes, which testifies to the needs of society in organizing.

\section{The Main Tendency in the Development of Tariffs in European Countries and in Russia}

Key trends in the development of markets of services of HCS in European countries over the last two decades can be summarized as followings:

- the decentralization of the system of management utilities HCS with the transfer of responsibility to local authorities;

- $\quad$ the privatization of most companies operating in the water supply system, heating, gas and electricity;

- the structural reform of HCS in a part of separation of kinds of activity (generation, transmission and distribution) of companies which operate in this market, with the aim of promoting competition in potentially competitive sectors;

- the establishment of the current regulatory regime, which main purpose is the creation of optimal conditions of modernization of the infrastructure of HCS while maintaining a balance of interests of operating companies and consumers.

Since 1999, the electricity market in the UK operates in the mode of competition. Since 2001, all the companies were divided into four activities, each of which will require a separate license for production, transmission, distribution and supply of energy (Electricity prices - Price systems, 2006; Eurostat Statistical books, 2007).

The main condition of entry into the market of provision of housing services in the UK is the licensing of all types. And also institutional specifics for companies in this market are:

- agreement on prices limits on power transmission, distribution of electricity is reviewed every 5 years. (in Germany - 5 years, in Finland - 4 years);

- compensation scheme for network operators, providing high quality services to consumers (The Electricity Distribution Customer Service Reward), which is designed to highlight and promote the company which carry out their activities most effectively and demonstrate best practice in relation to consumers. (1 million pounds );

- $\quad$ the introduction of a new model of regulation of tariffs - the RIIO model (Revenue = Incentives + Innovation + Production) (revenue=incentives+innovation+outputs). The RIIO model will be applied in reviews for price regulation from April 2013 (Decision' document: our final decision on the RIIO model, http://www.ofgem. gov.uk/Networks/rpix20/ConsultDocs/Documents1/Decision\%20doc.pdf, 2013).

Distinctive and positive side of tariffs in Germany is that the lowering of reducing the amount of income, which stimulates the most efficient operation, is placed. Since January 1, 2009 incentive regulation, which replaced the old system of tariff regulation based on the cost method of tariff calculation was enacted (The decree on incentive regulation, http://www.gesetze-im-internet.de/aregv/index.html, 2012). Incentive regulation involves the determination of the maximum allowed revenue (permissible revenue cap) of network operators (StromNEV, http://www.gesetze-iminternet.de/stromnev/_11.html, 2012 ). The basis for its determination became the costs of network operators in 2008. The regulation period is 5 years, for operators of gas supply networks the first period lasts 4 years. The aim of the new regulatory system is the creation of incentives to increase efficiency of functioning of the energy sector (GasNEV, http://www.gesetze-im-internet.de/gasnev/_10.html, 2012).

Later on each year, the maximum income will be adjusted to reflect market prices for the relevant services. Moreover, the amount will be reduced by $1.25 \%$ per year. This reduction is aimed to increase the productivity and the efficiency in the sector. The system of bonuses and penalties provides additional incentives for network operators to reduce costs: if costs exceed a fixed level for the previous year, the network operator will incur $25 \%$ of additional costs; if the cost is lower than the target value, it can save $25 \%$.

An important role in the regulation of the sector of water supply and water removal play industry and professional associations. In Germany there are six major associations - Association of municipal enterprises of HCS (Federal Network Agency. Monitoring Report, 2009), the Association of enterprises in the sector of water supply and water removal (Federal Network Agency. Annual Report, 2009), Association in the field of energy and water suppliers (Association of Local Utilities, http://www.vku.de/other-languages/english.html, 2015), Association of supplying water from 
reservoirs (German Association for Water, http://www.dwa.de/portale/dwahome/dwahome.nsf/home?readform, 2015), Associations of water management in Germany (German Association of Energy and Water Industries, 2015), the Technical-Scientific Association in the field of gas and water supply in Germany (Association of Drinking Water from Reservoirs, http://www.trinkwassertalsperren.de/). These associations have developed a system of benchmarking in the sector of water supply and sanitation (German Alliance of Water Management Associations, http://www.dbvw. de/txt110.ph).

In the European Union dynamics of prices for complex for housing and communal services and fuel during the 2000s was positive, both in nominal and in real expression excluding 2009. In other words, the rate of growth of prices for housing and communal services and fuel exceeded the rate of consumer inflation. However, the scale of this annual excess was small, being within $5 \%$.In the first half of the 2000 s the acceleration in the rate of growth of prices for housing and communal services was observed, in real terms they reached a peak in 2005. Subsequently, after some delay, a new peak in 2008 took place - on the wave of pre-crisis overheating of the global economy. In the 2009 year of crisis, despite the fact that the index of consumer prices in the EU rose by 1.5\%, rates for utility services remained almost unchanged, which resulted to reduction of the cost of housing in real terms in the past decade. However, in 2010, according to preliminary estimates, the rise in nominal and in real terms was resumed.

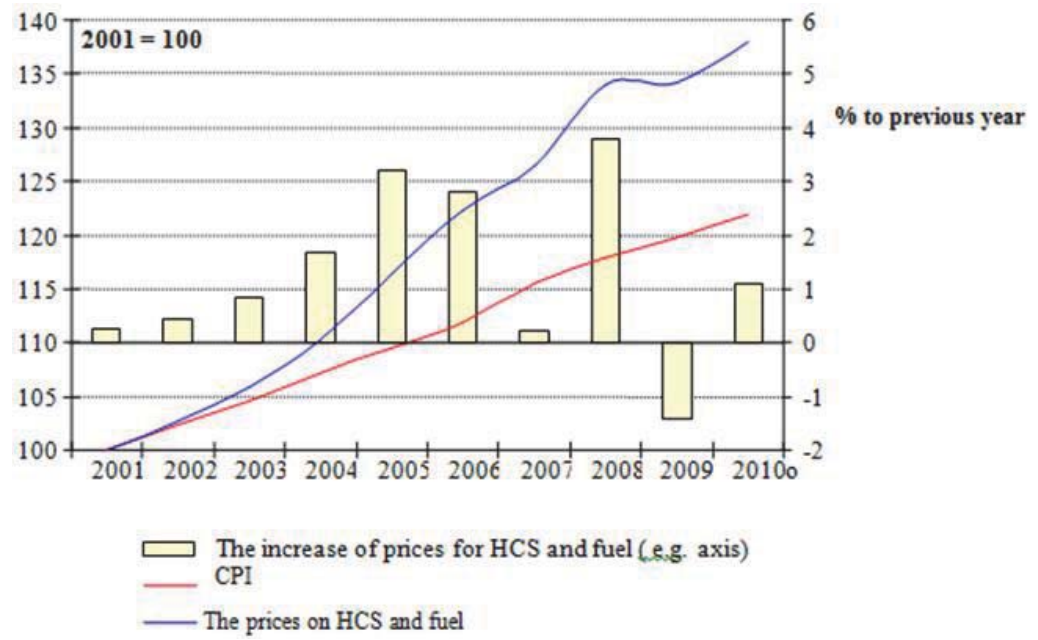

Figure 1 - Dynamics of nominal and real rates for public utility services in the EU-27 and the consumer price index, 2001 - 2010 (source - Eurostat data)

Examining the dynamics of tariffs for specific HCS, significant caveat should be made concerning the methodology of the European statistical system, namely the weights of the various components. According to classification COICOP (classification of individual consumption by purpose - ed.), approved by the UN, which conduct surveys of household budgets in category "Housing services, water, electricity, gas and other fuels" includes the costs of the rental of dwellings, as well as "imputed rent for housing services". This leads to the fact that the share of this category in the structure of consumer spending depends on the development of the rental market and the share of households living in rented housing, as well as calculation methods "contingent rent". In Russia the share of rent in the structure of expenditures for housing and communal services, even taking into account the rent for housing in the state and municipal Fund, is significantly less than $10 \%$ (according to the methodology of calculation of the price index Rosstat), and is not calculated "imputed rent". But in European countries, the rent is of great importance in the framework of consumer expenditures for housing and communal services, accounting for about one third of the price index for services of this group. 


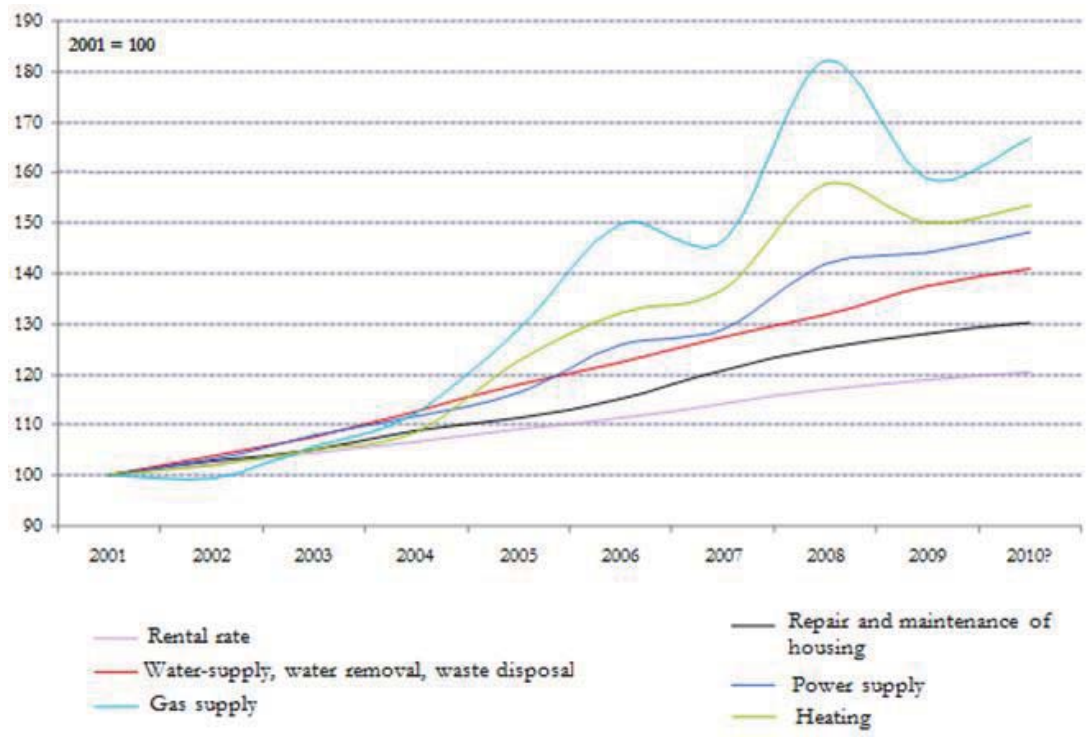

Figure 2 - Dynamics of tariffs for private housing and public services in the EU-27, 2001 - 2010, 2001 = 100 (source data Eurostat)

The rental rate is the factor that significantly inhibits the growth of average prices for housing and communal services in European countries. Each year it grows only 2 to 2.5 percentage points, and in 2009 - 2010, the growth rate was even lower. Prices for repair and maintenance of housing, which are another important factor when calculating the price index for housing and communal services, are also increasing steadily, but slowly, and at a rate of 2 to $4 \%$ per year, except for 2007, when they increased by almost 5\%, and the period 2009 - 2010, when the rate, in contrast, slowed and even decreased in 2010 according to estimation to less than $2 \%$. Services of water supply, water removal and waste disposal are rising a bit faster, but too slowly.

The main factor of significant fluctuations of the magnitude and the rate of growth of tariffs in the EU became prices for electricity, gas and fuel. Prior to 2003 , on average, they increased annually by about $4 \%$, moving within a single trajectory with other HCS. But in 2004, the tariffs for services of this group increased by 6.5\%, in $2005-2006$ by approximately 10\% per year, after a disappointing 2007, the growth rate in 2008 again exceeded 10\%, but in 2009, a drop of almost $4 \%$ was recorded.

The logic of the reform of HCS is based on change-over to payment services in accordance with their actual scope and quality. Payment at a reduced standard does not encourage saving measures, including the installation of metering devices. On the other hand, the overestimation of the tariff causes complaints of citizens-consumers of utilities.

In accordance with the standards of HCS of the Russian Federation, the volume of municipal services is calculated on the basis of consumption norms, or on the basis of meter readings.

In order to analyse the reasons for the increase in charges for public services, multifactorial nature of its calculation should be noted.

Monitoring data approved by the local government of standards indicate a significant difference in the consumption standards of public services, as between territorial entity of the RF, and between municipalities within the same region. It is necessary to indicate that, besides that there are a general an algorithm and established methods for calculating of tariffs, standards of consumption of utility services, approved by local authorities for the same for all parameters (design features, territorial factors and other) buildings in different municipalities can differ significantly. Taking into account that the ratio of the consumption of utility services has a physical meaning and primarily depends on the design features of buildings and climatic conditions, a large dispersion of values within a specific territorial entity of the RF spoke about the diversity in approaches to the regulation of the regulations by local authorities in the definition and adoption of standards.

In Russia, the tariffs for housing and communal sphere are shaped by a number of factors, shown in figure 3. 


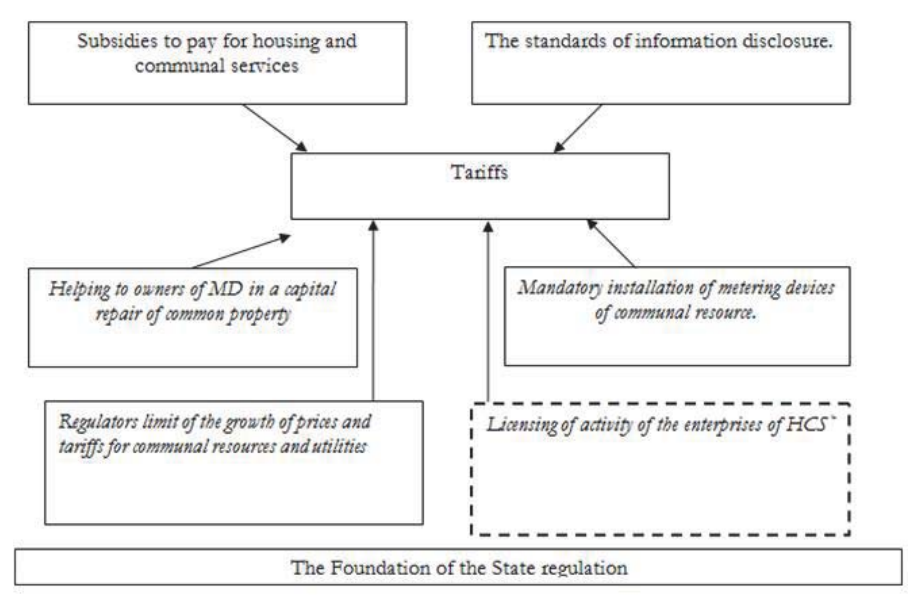

Figure 3 - The institutions affecting tariffs of housing and communal services of the Russian Federation

The price improvement of mechanism for providing HCS to consumers, differentiating of their value depending on the location of housing, degrees of comfort, land improvement are the regulator of marked economic transformation. In order to avoid non-payment for services and social tensions in the country the citizens ' solvency must be taken into account and social protection of the population must be ensured, which makes state regulation of price and tariff policy in the formation of the market of HCS. This would have a beneficial effect on the population's attitude to growth of tariffs. Negative social response also receives the quality of services, it does not change for the better.

It is evident from figure 3, the state is not required only by the participant (subject) HCS along with the sellers and consumers, but also performs on the market the specific role of the dominant entity. Not dealing directly with the satisfaction of the needs of members of society, it must regulate this process and to facilitate the effective achievement of a compromise between the interests of all participants with minimal cost society. This is due to the need to address economic and social processes in unity and cooperation. Thus, the state, unlike private enterprises, is interested in the efficient functioning of the economy as a whole. On the other hand, the state can be considered from the point of view of the provision of important social services (security, environmental protection and so on). That is, it is a specific company that provides a broad range of services.

The above facts indicate the necessity of providing marketing approach to state management in the sphere of HCS, both in general and when carrying out certain activities, regardless of their size. For successful practical solutions to complex public problems achievements in different fields of knowledge need to be effectively used. Among them is the marketing.

The decisions of state authorities without an objective and reliable information, extensive discussions and consultations in society, often cause considerable resonance and dissatisfaction with certain social groups. Therefore, to improve the efficiency of government without active use of marketing seems to be quite problematic, and the complexity of market processes and the active intervention of the state now require allocation in the system of marketing such varieties as state marketing (German Technical and Scientific Association for Gas and Water, www.dvgw.de/englishpages/dvgw/).

The aim of public marketing must be, first and foremost, the maximum satisfaction of material and spiritual needs of citizens within the allocated public expenditure. State marketing should examine needs and interests, i.e., the essence, structure, ranking, factors and trends.

Marketing in the activities of state agencies has certain characteristics, because these agencies are not always directly satisfies these needs, but only indirectly contribute to this. In comparison with tasks that solves marketing at the level of the individual enterprise, the purposes of government marketing is much bigger and more complex. So, if on HCS enterprise marketing provides sales and promotion of a narrow range of services of this company, at the state level it multidirectional that requires a comprehensive and balanced approach to the needs of the subjects. Besides, it is necessary to take into account such factors such as environmental, political and other. In the temporary plan state marketing activities designed for much more long term.

The second reason, which causes the need for active use of marketing, is the necessity of active influence on consumer preferences. The state can and should influence the formation of the correct consumer behavior of citizens in housing and the consumption of HCS. On the other hand, it should encourage manufacturers to the satisfaction of 
rational demand through complex state of marketing activities and tools. This means that the state marketing should be socially oriented. The main directions of state policy in the sphere of HCS should be to support and develop of competitions of organizations that provide relevant services.

For solutions of problems of HCS private enterprise has limited capacity and resources. Therefore, the state should take responsibility for solving complex and large-scale problems. To ensure the necessary level of competition the state has effective regulatory tools, which can be divided into direct and indirect. Therefore, the marketing concept of the public administration should provide more efficient and qualitative identification, formation and satisfaction of consumer's needs in the sphere of HCS.

One of the functions of government marketing can be also legislative regulation of the marketing (advertising) activity of subjects of the market of HCS in order to avoid negative impact on consumer preferences, creation of conditions for fair competition on the market.

The marketing tools should be used effectively at all stages of preparation, adoption and implementation of managerial decisions, including the adoption of effective laws. In particular, the tools of marketing communications that will allow to make a more open and democratic system of government must be used.

Public marketing must be used completed with all the tools of public administration, for example, planning, to identifying and finding ways to satisfy the real needs of people.

To make good management decisions and ensure effective functioning of the HCS the government bodies need not only general information about the condition of the market of HCS, but also specific data about individual companies, which can be obtained through public or private research organizations.

Thus, the state marketing should become an integral part of the system of state management in the sphere of HCS, and its main problem is the maximum satisfaction of the reasonable needs (interests) of the population at the expense of producers of services for which the state should create the most favorable conditions for development.

State marketing should be used primarily to solve the following main tasks:

- clarification of goals and problems for the development of sphere of HCS;

- analysis and forecasting of public demand for HCS;

- formation of positive image of HCS as sector of the economy;

- the development of competition, ensuring equal conditions for all subjects of the market activity;

- legislative support and the creation of appropriate conditions for the implementation of laws;

- stabilization of the market of HCS.

In Russia, the individual elements of the marketing are already in use in state bodies activities, however, this usage is not always complex and focused, and for their practical implementation is often lacking the necessary resources. Today at the level of ministries begin work on the creation of units that perform various marketing functions. Their tasks, working methods and activities will differ from the activities of the marketing departments of businesses. But the point is not only in the creation of separate divisions, but in the transition to the marketing concept of public administration, which involves the extensive use of marketing techniques at all stages of adoption and implementation of managerial decisions. Thus in this complex all the levers of public administration should be used: legal, organizational, financial, etc.

Table 1 - The growth rate of consumer prices, nominal income and tariffs for HCS in Russia for the period 2002-2012, in $\%$ to previous year (Drugov, A. A., Safin, A. R., Sendetzky S. C., 2005; German Technical and Scientific Association for Gas and Water, www.dvgw.de/english-pages/dvgw/)

\begin{tabular}{|l|c|c|c|c|c|c|c|c|c|c|c|}
\hline & $\mathbf{2 0 0 2}$ & $\mathbf{2 0 0 3}$ & $\mathbf{2 0 0 4}$ & $\mathbf{2 0 0 5}$ & $\mathbf{2 0 0 6}$ & $\mathbf{2 0 0 7}$ & $\mathbf{2 0 0 8}$ & $\mathbf{2 0 0 9}$ & $\mathbf{2 0 1 0}$ & $\mathbf{2 0 1 1}$ & $\mathbf{2 0 1 2}$ \\
\hline CPI & 15,1 & 12,0 & 11,7 & 10,9 & 9,1 & 11,9 & 13,3 & 8,8 & 8,8 & 6,1 & 6,6 \\
\hline Per capita nominal income of the population & 28,9 & 31,0 & 24,0 & 26,5 & 25,7 & 23,6 & 18,6 & 13,0 & 5,2 & 2,8 & 8,4 \\
\hline HCS tariffs & 48,8 & 28,7 & 23,5 & 32,7 & 17,9 & 14,0 & 16,4 & 19,6 & 13,0 & 11,7 & 9,4 \\
\hline
\end{tabular}

Source: Federal state statistics service of the RF

Thus, the analysis of data of the Table shows that the growth rate of consumer prices always has a social character and background. However, for socially vulnerable segments of the population, particularly for pensioners, it was a constant concern, which was forced to raise pensions, benefits, wages in the government payroll ; perhaps even above a realistic level according on the fiscal capacity of the country.

In the mid-2000s, the situation seems to have reached a relative stability: since 2003 , the growth rate of nominal income is almost always (except for 2005) exceeded the growth rates in the housing sector, and in 2010 - 2011 the 
growth rate of tariffs was reduced to quite low levels, even taking into account inflation, but although still slightly exceeded them. However, in 2011 - 2012, the growth rate of the real price of HCS relative to the previous year were significantly below $5 \%$, which is quite a normal situation for European countries.

But in 2009-2010, the situation has changed not for the better: the growth of HCS increased again. In 2009, the nominal growth rates reached a maximum level for the last four years.

Statistical data on specific housing and communal services indicate that approximately up to 2005, the services can be divided into two categories: electricity and gas, on the one hand, and other essential housing services, on the other hand.

The cost of services of electricity and gas to 2005 increased by about twice slower than in other utility services. In the second half of the 2000s, the growth of tariffs for gas and electricity became close in with indicators for other services, and in 2010 even can considerably surpass them coming near to $22-23 \%$ compared to the previous year, while water and heating can grow only by $15-20 \%$, and the maintenance and repair of housing - and at $10 \%$. Particularly noticeable in recent years are increasing gas prices, and in this the tendency to their planned exit on the same level with European (including, of course, the transport component) can be noticed.

The increase of tariffs for housing and communal services in itself is a significant factor in the acceleration of inflation. The direct contribution of the growth of tariffs for HCS in consumer inflation in recent years was steadily about 1.5 percentage points. Thus, the reduction of the rate of growth of prices for HCS 2 times will help to reduce the overall rate of inflation by about 0.7-0.8 percentage points.

\section{Social Practices in Reforming the HCS in Russia}

Tariffs in the sphere of housing and communal services should be considered as part of social practices in the HCS sector. Let's refer to the question of the process of institutionalization of social practices on the example of housing and communal services. In the process of institutionalizing there are some social problems in the society, the reason is the divergence of interests of the whole society with the interests of specific individuals in the housing arrangement and reproduction of HCS, the need for housing and communal services has both mass and individual character, and the latter runs the risk of not being recognized as socially significant. Such institutions perform their own functions and standard operations, they can be not seen for a long time, do not present values and do not perform functions that meet the needs of society in a particular cultural dominance.

The need for social recognition of the Institute of public utilities, as significant for the economic and social functioning of society is obvious, it is from the work of this institution largely depends on the representation of the population of the stable development of society.

The reforming of HCS in Russia affects a very wide range of relationships, which involved a majority of the population of cities and towns. The housing reform provides for radical reform of the system of housing management, i.e. the whole social institution, which is based on the reconstruction of the interaction and relations between participants in the market. According to researchers of A. C. Yermishin and L. C. Klimenko, "the social importance and significant positive externalities characterize HCS as a socially significant private benefit, production and financing of which is accompanied by formation of special relations and institutions." (The availability of housing and communal services in Russia: Myths and reality, 2010).

As can be seen, the results of social surveys the reforming of social institution can lead to social instability (In June, the rating of the main problems of the country is headed by the situation in the housing sector, //http://mrr-sro.ru/, 2013).

To ensure social stability of the state and the territorial entity of the RF of local authorities used a variety of tools, namely:

- federal, regional, municipal, local development programs for major repair: dilapidated housing, communication networks, water supply, cleaning and transportation of wastewater, and so on;

- $\quad$ the provision of public subsidies to pay for housing and communal services of the Russian Federation subjects and local authorities;

- $\quad$ the tariff policy, i.e., the pricing services of housing are formed on the territory of the municipality and approved by a regional body to monitor tariffs.

Considering each of these tools let's refer to the official statistics and reports on Russia and the Rostov region (In June, the rating of the main problems of the country is headed by the situation in the housing sector, //http://mrr-sro.ru/, 2013).

Implementation of Federal and social programs is a priority aims of the ministry of housing and utilities for the 2011 
reporting year, the current 2012 year and the planned period 2013 - 2015, from the Constitution of the Russian Federation, Federal laws concerning housing and communal services reform in the period 2007-2013 such aims are:

1. Improving the living conditions of citizens, creating a safe and favorable condition of their living;

2. Creating the conditions to bring the infrastructure in accordance with quality standards, providing comfortable living conditions of the population of the Rostov region, improvement of the ecological situation. The main indicator of the improvement of living conditions of citizens, is the index of "Proportion of multi-apartment houses with wear of more than $31 \%$, in which were overhauled, in the total number of apartment houses requiring major repairs". Metric values amounted in 2010 to $2.8 \%$ (while the target value of 2.5\%), in 2011 to $1.4 \%$ (while the target value of - 1.1 percent); in 2012 and 1.1\%, for the planning period: 2013 - 0,6\%, $2014-$ - 6,65\%, $2015-0.7$ percent (Russian statistical Yearbook, 2014).

Analysis of social stability, regional tariff policy on the level of territorial entity of the RF was held in various studies (Nerovnya, I.E. and Oboimova N.T., 2012; Nerovnya I.E. and Oboimova N.T., 2012). It should also be considered the prescriptive regulation, which happens with the help of regulations of the regional government. For example: comparing indexes of consumer prices (tariffs) with other types of services, it should be noted that the rate of growth of prices for HCS ahead also medical services and the price for pre-school education. In the Rostov region a resolution, dated 27.06.2012 No. 56 "On approval of the coefficients of the rising cost of housing and communal services for 2013 - 2015" was adopted and approved the coefficients of the rising cost of housing and communal services for 2013 - 2015, they are presented in the Table:

Table 2 - The coefficients of the rising cost of housing and communal services for 2013 - 2015 in the Rostov region, Russia (The decision of the Government of the Rostov region dated 27.06.2012 No. 56, http://special.donland.ru, July 2014)

\begin{tabular}{|l|c|c|c|}
\hline Type of Service & 2013 год (к 2012г.) & 2014 год (к 2012г.) & 2015 год(к 2012г.) \\
\hline Heating & 1,150 & 1,271 & 1,411 \\
\hline Water-supply & 1,116 & 1,233 & 1,364 \\
\hline Water removal & 1,116 & 1,233 & 1,364 \\
\hline Hot-water supply & 1,150 & 1,271 & 1,411 \\
\hline chemical water treatment & 1,116 & 1,233 & 1,364 \\
\hline Recycling (disposal) of solid waste & 1,138 & 1,285 & 1,449 \\
\hline Electricity (budget consumers, including street lighting) & 1,116 & 1,239 & 1,375 \\
\hline Gas supply with natural gas (budget users) & 1,150 & 1,323 & 1,521 \\
\hline Boiler-furnace fuel and coal & 1,093 & 1,149 & 1,200 \\
\hline The removal of liquid waste & 1,116 & 1,233 & 1,364 \\
\hline
\end{tabular}

The highest rates of growth of tariffs by 2015 are projected to supply natural gas: the annual growth rate is $15 \%$ of the amount, the maximum established by the RF Government. Services of heating and hot water on 1,411, power supply on 1,375 points, this group of services are in the same complex JSC "Donenergo", i.e. setting of the tariffs will be carried out almost at the maximum permissible rates of growth of tariffs.

\section{The Necessity for Implementation of Marketing Approaches in the Housing and Communal Sector in Russia}

Russia's solution to the problem of deducing the HCS from the crisis through the development of market relations in this sphere continues more than 20 years without significant results. One of the big problems in the housing and utilities reform, limiting its development, is the lack of measures for the establishment of market-oriented housing organizations. In the housing law, the literature only the most General approaches to the de-monopolization and development of market relations in the sphere of $\mathrm{HCS}$, involving the separation of the functions of ownership, management and maintenance of the housing stock, the necessity for funding and involving in this sector organizations of all forms of ownership are developed. The implementation of these approaches already puts housing organizations in new conditions that require their management knowledge and skills. However, management methodology, adapted to the peculiarities of the activities of housing organisations and to ensure its market orientation, is missing.

The development of the marketing methodology and its adaptation to housing will equip management housing organizations with the knowledge and skills they need for survival and successful functioning in market conditions. There is an objective necessity for the introduction of marketing management in practice of housing organizations of HCS. 
Implementation of priority measures of the reform of HCS, such as financial recovery of enterprises, modernization of fixed assets will not be successful in the absence of market-oriented housing organizations, ensuring their economic interest due to the high degree of social adequacy activity.

The introduction of marketing management in the sphere of housing determines the necessity for the development of its methodology towards solving existing problems and its adaptation to the peculiarities of the functioning of the HCS organizations. The main problems of marketing management, which are of fundamental importance, are essential from the point of view of their successful implementation in housing are followings (Novikova, N.G., 2005; Oboimova N.T., 2012):

- lack of the concept of strategic marketing, which would not only provide the interrelated development of marketing strategies but also their implementation;

- the absence of a holistic concept of the analytical system, which would allow to combine the efforts of all levels of management in the direction of obtaining information to substantiate and to test marketing solutions, as well as would contribute to the integration of marketing in the management of housing organizations;

- $\quad$ the problem of assessing the quality of marketing management;

- absence of model in marketing management, which would allow to take into account all the features of ruling housing organizations of new generation.

\section{Conclusion}

Housing and communal services (HCS) is complex which represents the largest industry in the Russian economy, whose share in fixed assets is more than $26 \%$ and includes 56.6 thousand enterprises and organizations, municipal, private and mixed to provide (HCS). Currently, the population of Russia is provided by16 types of housing and 41 species utilities.

1. Russia's transition to a market economy determined the necessity for radical changes in the content and the mechanism of state regulation of the management of housing and communal services as the material basis of the provision of vital utility services to the population and organizations. Due to the large gap in income and social problem of the growing weight of the elderly population it is necessary to develop the mechanism of pricing as more transparent and Pareto-optimal in order to support tariffs of HCS.

2. Economic policy of administrations (municipalities) should include the preparation and implementation of priority of urgent measures with regard to bringing economically justified tariffs in accordance with the existing conditions (dynamics of income and purchasing power of the population and level of development of the regulatory framework) and to be directed to the stabilization of the system of control of housing.

3. While using any of the methods of regulation of tariffs (for one year, long-term) mandatory standards for quality of services, works and basic standards resources (fixed assets, labor costs, material costs, and so on) necessary to ensure high-quality delivery of heat, electrical energy, water, wastewater treatment, recycling (disposal) MSW should be developed and established. Only after establishing such regulations it is possible to develop terms of reference for the development of the production program for public utilities, adopt and monitor implementation of such a program, and to be confident in establishing economically justified tariffs (Rate $=$ Production/sales Volume).

4. However, in the absence of a clear and reasonable methodology for determining consumption norms established at the Federal level and clear regulation of their use in situations of presence/absence of household and/or individual metering of resource, such transfer will not give a positive effect.

There are calculations for management companies and HOA with RDF and the OCC for the resource in the absence of metering devices.

The introduction of new organizational and legal forms of management and operation, changing institutional environment industry creates preconditions for the investment attractiveness of enterprises of HCS. For the effective functioning of management companies, development of concession relations required institutionally mature regulatory and methodological support.

Market reforms in the country's economy changed significantly the structure of money expenditure of population, social welfare and the demand for consumer goods and services. As a result, the contents of housing and communal services are changing, as well as forms of supply and demand for these services in terms of scope and quality component. Today enterprise utility services are not adapted to market conditions which find expression in the lack of competitiveness of services, cost principles farming, insufficient management and customer service.

5. Having Considered the process of institutionalization of the HCS as a reflection of public perceptions about the 
stable development of society and conducting relevant research, we note that the social practice of service utilities take into account the historical and international experience in providing various kinds of service.[8] There are sustainable forms of social practices within the social service Institute, in implementing of housing, through which a housing were organized, where people realize their needs in security that ensures the continuity of social ties within a social organization.

Pricing policy for public utilities detects a contradiction, on the one hand, between a wide range of services and agents that shows the democratization processes in the maintenance and strengthening of processes of government, and on the other hand, rising prices and low quality of provided services.

6. The concept of socially responsible marketing and marketing interaction with consumers is exactly that methodology, following which the activities of housing organisations will allow them to become marketoriented, align their economic interests with the interests of the institutional actors of the market environment, and on this basis to ensure institutionally mature state of housing. Thereupon, the development marketing management methodology in the HCS sector in the conditions of formation of market relations is very important.

\section{References}

Electricity prices - Price systems 2006. Eurostat Statistical books. 2007

The RPI-X@20 'Decision' document: our final decision on the RIIO model. The Handbook for implementing the RIIO model: sets out 'how' the RIIO model will work in practice [Online] Available: http://www.ofgem.gov.uk/Networks/rpix20/ConsultDocs/Documents 1/Decision\%20doc.pdf (April 2013)

The decree on incentive regulation ARegV (2012) [Online] Available: http://www.gesetze-im-internet.de/aregv/index.html

Article 11 StromNEV (2012) [Online] Available :http://www.gesetze-im-internet.de/stromnev/_11.html (January 2015

Article 10 GasNEV (2012) [Online] Available http://www.gesetze-im-internet.de/gasnev/_10.html (January, 2015)

Federal Network Agency. Monitoring Report. 2009. P.6

Federal Network Agency. Annual Report. 2009.

Association of Local Utilities (Verband kommunaler Unternehmen e.V. - VKU)(2009-2014) [Online] Available: http://www.vku.de/otherlanguages/english.html (January, 2015)

German Association for Water, Wastewater and Waste (Deutsche Vereinigung für Wasserwirtschaft, Abwasser und Abfall e.V. - DWA) [On-line] Available: http://www.dwa.de/portale/dwahome/dwahome.nsf/home?readform (January, 2015)

German Association of Energy and Water Industries (Bundesverband der Energie- und Wasserwirtschaft e.V. - BDEW) [On-line] Available: http://www.bdew.de/bdew.nsf/ID/DE_Home (January, 2015)

Association of Drinking Water from Reservoirs (Arbeitsgemeinschaft Trinkwassertalsperren e.V. - ATT) [Online] Available: http://www. trinkwassertalsperren.de/

German Alliance of Water Management Associations (Deutscher Bund verbandlicher Wasserwirtschaft e.V. - DBVW) [Online] Available: http://www.dbvw.de/txt110.php (January, 2015)

German Technical and Scientific Association for Gas and Water (Deutsche Vereinigung des Gas- und Wasserfaches e.V. Technischwissenschaftlicher Verein - DVGW) [Online] Available: http://www.dvgw.de/english-pages/dvgw/ (January, 2015)

Drugov, A.A., Safin A.R. and Sendetzky S.C. (2005) State marketing as an important factor of improvement of the mechanism of management of socio-economic processes in society. Marketing in Russia and abroad, 4, 101-107.

The availability of housing and communal services in Russia: Myths and reality (2010) Journal of institutional studies (Journal of institutional research). - Volume 2, 2, 138-139

In June, the rating of the main problems of the country is headed by the situation in the housing sector. (2013) Electronic resource: the website Self-regulatory organization NP Agrocomplex "Mezhregionrazvitiem" [Online] Available: //http://mrr-sro.rul

Russian statistical Yearbook. (2014) Moscow: Rosstat

Nerovnya, I.E., Oboimova N.T. (2012) The main areas of monitoring and reform of the complex, HCS of the region. Bulletin of the Institute of friendship of peoples of the Caucasus "Theory of Economics and management of national economy", 4-24, 98-105

Nerovnya, I.E. and Oboimova N.T. (2012) Challenges and key factors which are influencing the formation of regional tariff policy in the sphere of housing and utilities (for example, the Rostov region). Vestnik of the Irkutsk state technical University, I. 64, 5, 229-236

The decision of the Government of the Rostov region dated 27.06.2012 No. 56 "On approval of the coefficients of the rising cost of housing and communal services for 2013 - 2015" (2014) [Online] Available: http://special.donland.ru (July 2014

Novikova, N. G. (2005) Methodology marketing management in the sphere of housing and utilities sector in the conditions of market relations development (doctoral dissertation). Baikal state University of Economics and law. Irkutsk, Russia

Oboimova, N.T. (2012) Study of institutional changes in the provision of housing and communal services on the territory of municipalities (according to the materials of the Rostov region). Vector science of Togliatti state University, No. 1, 177-180. 